Article

\title{
Spatial Exploration of Economic Data-Insight into Attitudes of Students towards Interdisciplinary Knowledge
}

\author{
Simona Sternad Zabukovšek *(1), Polona Tominc, Samo Bobek and Tjaša Štrukelj \\ Faculty of Economics and Business, University of Maribor, 2000 Maribor, Slovenia; polona.tominc@um.si (P.T.); \\ samo.bobek@um.si (S.B.); tjasa.strukelj@um.si (T.Š.) \\ * Correspondence: simona.sternad@um.si; Tel.: +386-2-22-90-248
}

Received: 28 May 2020; Accepted: 25 June 2020; Published: 30 June 2020

check for updates

\begin{abstract}
This paper uses the technology acceptance model (TAM) framework for the research of economic and geography students' attitudes towards interdisciplinary knowledge. Based on the SmartPLS Structural equation modelling SEM variance-based method, research results were gained through analysis of survey data of economic and geography students. They participated in the Spationomy project in the period of 2017-2019. Online questionnaires were fulfilled before and after students' participation in the project and their future behavioural intention to use interdisciplinary knowledge was analysed. Based on the research, we can confirm that the Spationomy project has achieved its purpose, as both groups of students (economic and geography students) have acquired interdisciplinary knowledge and students intend to use it also in the future. Therefore, we can argue that the students included in the project in practice gained recognition of systems thinking about the importance of mutual interdisciplinary cooperation towards achieving synergies. The results also show that TAM can be successfully implemented to analyse how students of economics and geography accept the use of interdisciplinary knowledge in the learning process, which is an important implication for management and education as well as from the theoretical implications viewpoint. While effective analysis using TAM has been used successfully and relatively frequently in economics and business field, we have not found relevant examples of its implementation in the broader field of geography. However, the acceptance of geographic information system (GIS) or other information technologies/information software (IT/IS) tool-based approaches of analysis in the geography field may be of most importance. Therefore, also, this represents an important implication for the research area.
\end{abstract}

Keywords: spatial exploration; economic data; economic students; geography students; TAM; PLS SEM; interdisciplinary knowledge; holism; interdependence; strategic management.

\section{Introduction}

Nowadays, an interdisciplinary scientific approach that combines management sciences and natural sciences is important in more and more situations [1-4]. Therefore, it is also important, that students today think and work in an interdisciplinary context [5], taking all important but only the important aspects and their interdependence into consideration [6,7]. One of the growing areas of research is also an interdisciplinary field that combines several viewpoints from economics and business on one side and geography (i.e., spatial science, taking spatial aspects of the geography into account) on the other side.

Since 2004, their importance, expressed in the number of articles published in the SCOPUS database, has been growing rapidly, especially since 2015 (see Section 2.3). Tominc et al. [4] pointed out that the importance of the spatial components, which became characteristic of most economic 
data, is rapidly increasing. This is also reflected in the research papers published in the last few years [8-11]. All recent studies from this research field have in common the recognition of systems thinking mutual interdisciplinary cooperation importance [12], reflected in the highly valued need of combining geospatial aspects in the analysis of economic data.

An essential goal of the Spationomy Erasmus+ project that represents the background of our research is to improve students' interdisciplinary skills by connecting the study fields of economics, business, management and business informatics (in the continuation economic students study fields) on one side and geoinformatics, geography, spatial information, remote sensing and so forth (in the continuation geography students study areas) on another side $[13,14]$. Our contribution stems from the importance of the ability to integrate business/management knowledge and spatial knowledge to make students effective future employees, entrepreneurs, business owners. Therefore, in the present study, students' behavioral intentions for the future use and incorporation of interdisciplinary knowledge of economic/business science and spatial science were analyzed, considering two groups of students (economic students and geography students) in two intersectional times (at the beginning and the end of the project cycle). As already mentioned, data were obtained within Erasmus+ Strategic Partnership Project called Spationomy, which started in 2016. We studied four data groups, namely economics students before the start of the project cycle (EcoBe) and at the end of the project cycle (EcoAf) and geography students before the beginning of the project cycle (GeoBe) and the end of the project cycle (GeoAf). We determined whether there are statistically significant differences between groups of students with different knowledge backgrounds and how their mutual interdisciplinary cooperation in the project influenced their attitude and behavioral intention to use interdisciplinary acquired knowledge of spatial and economic components in the future.

The main goal of the present paper is to explore factors that significantly affect the acceptance of the use of interdisciplinary knowledge by students before and after Spationomy project cycle and examination of factors that affect their intent to use this knowledge in the future. As mentioned in the abstract, the conceptual model of our research is based on the TAM-the adapted TAM was used to check the integration of interdisciplinary knowledge of economics and geography students, for two groups of students and two different time sections. In this paper, TAM is used to study the impact of students' internal beliefs (perceived usefulness-PU and perceived ease of use-PEOU) on attitudes (AT) and future intention (behavioral intention-BI) $[15,16]$ of the use of interdisciplinary knowledge in future business and geography practice.

The paper is structured as follows-section Theoretical backgrounds (Section 2) consist of the introduction of mutual interdisciplinary cooperation towards achieving synergies (Section 2.1), following by the research of Spatial exploration of economic data-methods of interdisciplinary analytics and research about accepting spationomy interdisciplinary context and spationomy information technologies (Section 2.2), followed by the study of bibliometric analysis (Section 2.3). Section 3 introduces the research model and hypotheses tested. Section 4 is dedicated to the methodology used and Section 5 to research results and analysis (measurement model-Section 5.1, structural model and hypotheses tested-Section 5.2). Next section (Section 6) is devoted to the discussion and the last section (Section 7) to the conclusions of this paper.

\section{Theoretical Background}

\subsection{Mutual Interdisciplinary Cooperation Towards Achieving Synergies}

Achieving more holistic results requires the synergy of mutual, creative interdisciplinary collaboration between experts of different perspectives, that is, various fields of expertise. This applies to both the business world (organizations) as well as for any period of human life and all areas of our personal and business development and operations [4,17-19]. In our work, we, experts, need to be attentive to all those aspects that are, according to our subjective assessment resulting from our professionalism, necessary. As we are objectively incapable of considering all possible aspects, we must 
reasonably limit them to make them manageable. The content of so far written in this chapter is based on the findings already published back in 1974 when Mulej [20] published the first results of the findings of Dialectical Systems Theory, which emphasizes the requisite holism and interdependence. In this and his further research [6], the author also highlights and stresses, in particular, the importance of focusing on achieving synergy, the significance of the cybernetic approach and the ethics and social responsibility of the development and operations of individuals and organizations. It advocates a comprehensive approach to achieve the integrity of results.

The necessary and sufficient integrity—requisite holism and interdependence are also emphasized by the voluntary, optional standard on corporate social responsibility (for-profit and non-profit organizations)-ISO 26,000 [7]. ISO 26,000 is initially intended for all organizations and their social responsibility but it can also reasonably be applied on personal responsibility. It derives from the governance and management of organizations. It emphasizes their synergy with the following core subject areas-human rights, labor practices (employment), the environment, fair operating practices (ethical conduct), consumer issues (rights), community involvement and development. As a comprehensive, all-inclusive and necessary present mind-set, ISO 26000, similar like Mulej et seq. [20], emphasizes holistic approach (the necessary and sufficient integrity) and interdependence, thus optionally introduces the lessons of Dialectical Systems Theory into business practice. ISO 26,000 recommends social responsibility as part of an organization's ethics to be derived from the organization's governance and management [12,21-23]. Governance and management are focused on sustainable development if the organization follows a strategic model that considers the need to innovate the soft factors of the organization - values, culture, ethics and interests of all stakeholders-to innovate its governance (and thus management) [24].

An organization's development and operation based on systems thinking $[6,20,25,26]$, we also must take into account the findings of cybernetics on both a personal and organizational level [27,28]. Also, cybernetics emphasizes mutually creative interdisciplinary cooperation to facilitate the governance and management of complex situations and especially explicitly emphasizes the importance of feedback information, to improve the next cycle of development and operation. This ensures that key oversights do not occur in resolving a complex situation and discourages excessive specialization.

The achievement of mutual creative interdisciplinary cooperation can be promoted during the educational process by using modern teaching methods and/or networking of courses and different disciplines. Thus, it is possible to develop transversal/transferable competencies that are needed for different types of professions and different jobs within them $[4,18,19]$. In this way, employees are better prepared for the needs of the practice so that they can perform the required tasks more easily and successfully. Employers, on the other hand, hire better-prepared employees, who are more and more capable of independent and interdependent work [17].

\subsection{Accepting Spationomy Interdisciplinary Knowledge, Enabled by the Computer Tools}

The connection between the two, in the title of the article mentioned fields, is expressed in the term Spationomy, which reflects, on the one hand, the interdisciplinary nature of the field and on the other hand, calls for methods and innovative ways of imparting interdisciplinary knowledge to students of both fields. The term Spationomy is coined by combining the words "spatial" and "economy" [4].

The spatial dimension or characteristic of economic data is an important component of their information value, as demonstrated by the research results [8,9,29-32]. The added value of combining geospatial considerations in economic data analysis that is nowadays much appreciated has also been recognized in higher education.

The perceived importance of the ability to integrate geography knowledge-geography and economics knowledge, also led to the strategic partnership from the two economics/business-oriented departments (Moravian University College Olomouc, the Czech Republic and the University of Maribor, the Republic of Slovenia), the department from Palacký University Olomouc (the Czech Republic), oriented toward geoinformatics and the department from Ruhr University Bochum (Germany), 
oriented towards geomatics [14]. The partnership conducted a successful Erasmus+ project, entitled Spationomy, which ran between 2016 and 2019. The success of the project's results then enabled the launch of the Spationomy 2.0 project, started in 2019, which, based on identified key lessons from the first programming period, intensified the introduction of gamification in the acquisition of interdisciplinary skills.

An important goal of the Spationomy project is, therefore, to improve students' interdisciplinary skills by integrating the fields of geoinformatics, geography, spatial sciences, remote sensing and so forth on one hand [13] and economic and business sciences on the other. The biggest challenge in "spationomy education" was convincing students of economics and business why they should learn about geographical aspects; and vice versa, what makes sense for geo-students to think about economic categories [14]. This challenge also led to the systematic data collection of perceptions and responses of students who participated in the project, intending to record changes of students' perceptions regarding the adoption of this kind of interdisciplinary knowledge and record the process of building positive attitudes towards the use of the interdisciplinary "spationomy" knowledge.

Spationomy uses information technology from geo research areas, that is, Geographical Information System (GIS), information technology from economics, that is, Decision support systems and information technology from business studies, that is, Enterprise Resource Planning (ERP) extended with GIS. Acceptance of technology-enabled and facilitated knowledge must be associated with problem domain where technology is used and applied-in the area of spationomy it means on the areas of geo/economics/business. Information technology is often related to interdisciplinary knowledge, which is embedded in information technology and which is also required to use information technology on the advanced and more mature level; same is the case of spationomy. The use of GIS and business solutions to which GIS modules are added require interdisciplinary knowledge from geography and economics and business fields-the interdisciplinary knowledge of spationomy. Knowledge and associated technologies can be used at a fundamental level of application and expertness or they can be applied at a sophisticated and more advanced level. As the issue of the use of knowledge and associated technologies becomes increasingly important, it is not unexpected that research on the adoption and acceptance of technologies within organizations gained importance (for example see Reference [33]).

Several theoretical models have been used to research the determinants of acceptance and the use of information technology, such as the theory of reasoned action (TRA; [34]), the theory of planned behavior (TPB; [35]), the theory of the technology acceptance model (TAM; [15,16]), innovation diffusion theory (IDT; [36]), stage model (SM; [37]), technology-environment-organization (T-O-E; [38]); and resource-based view (RBV; [39]. Compared to competing models, TAM is believed to be more parsimonious, predicative and robust [40-42] and so among the theoretical models, it is most widely used by researchers $[15,16,33,43,44]$. TAM posits that two beliefs - perceived usefulness (PU) and perceived ease of use (PEOU)—are of primary relevance for computer acceptance behavior [16]. Perceived usefulness (PU) is defined as "the degree to which a person believes that using a particular technology would enhance his or her job performance" [15] (p. 320). Perceived ease of use (PEOU) in contrast, refers to "the degree to which a person believes that using a particular technology would be free of effort" [15] (p. 320). The two central hypotheses in TAM state that perceived usefulness (PU) and perceived ease of use (PEOU) positively influence an individual's attitude (AT) towards using a new technology, which in turn affects his or her behavioral intention (BI) to use it. Finally, the intention is positively related to actual use (U). TAM also predicts that perceived ease of use (PEOU) influences perceived usefulness (PU), as Davis et al. [16] (p. 987), put it, "effort saved due to the improved perceived ease of use may be redeployed, enabling a person to accomplish more work for the same effort." The key purpose of TAM is to provide a basis for tracing the impact of external factors on internal beliefs, attitudes and intentions [16] (see Figure 1). 


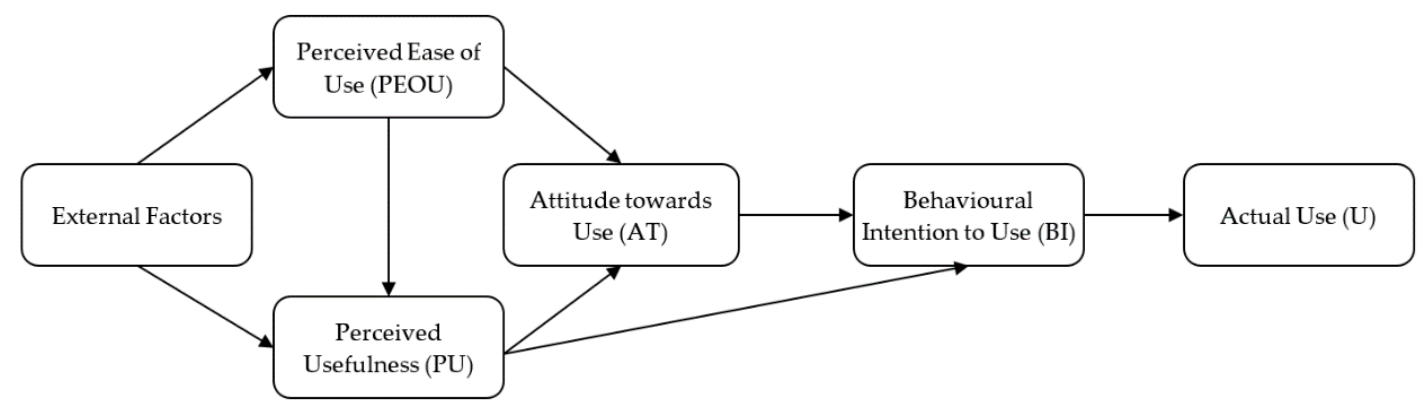

Figure 1. Initial technology acceptance model (TAM) [15,16].

The initial TAM is well established and tested and a variety of extensions regarding external factors by examining the antecedents of perceived usefulness (PU) and perceived ease of use (PEOU) have emerged such as TAM 2 [40] and TAM 3 [45].

TAM, in its initial or extended version, has been used by different researchers researching acceptance of different technologies. One of such areas related to spationomy is the acceptance of ERP solutions, which nowadays often have GIS modules embedded. TAM showed to be the most appropriate model to study the adoption of business solutions [33,46-48]. Even though TAM can be applied to a variety of technologies, the extensions and modifications of TAM are needed when analyzing specific information technology [49]. Same is true also for researching ERP acceptance where they apply extended and specific external factors [18,33,44,46-54]. Majority of such studies is focused on technology acceptance by employees in organizations and the majority of findings are related to such studies.

The research studies target at examining factors affecting the ERP systems acceptance by students are less frequent. One of the first surveys conducted among students regarding ERP [55] examined students' willingness for change on behavior intention (BI). Case studies were used by Bradley \& Lee [56] to investigate the correlation between training satisfaction and the perceived ease of use (PEOU), perceived usefulness (PU), efficiency and effectiveness in implementing an ERP system at a middle-sized university. Scott and Walczak [57] investigated students' cognitive engagement, earlier experience, computer fear and organizational support as determinants of computer self-efficacy in using the multimedia ERP system's training program. Sternad Zabukovšek et al. [58] examined how economics and business students adopt ERP solutions and the factors that shaped their intention to apply this knowledge in the future, by implementing the expanded TAM by the following external constructs-(1) students' personal characteristics and information literacy, (2) perceived system and technological characteristics of ERP solutions and (3) perceived support within the study process. Research results revealed that several dimensions of the three multidimensional factors play an important role in shaping the attitudes towards acceptance of ERP solutions by students.

Research studies based on TAM are in the geography field rather seldom [59-64]. Research, including geography students, are even more rarely. Adu Gyamfi [65] extended TAM to examine factors that influence the acceptance of Web 2.0 technologies for the pedagogical purpose of geography students, future teachers, from Ghana. Tan [66] researched the degree of technology acceptance of handhelds in local secondary education with specific application to the use of personal digital assistants for geography fieldwork, based on a group of 39 secondary students from Singapore government school. We did not find any other important research in this area. This indicates the importance of this research paper, which continues to present the findings of bibliometric analysis.

\subsection{Bibliometric Analysis}

With the purpose of emphasizing the relevance of the literature analysis of the interdisciplinarity of spationomy, especially in the cross-section of geo/economics/business fields and with stress on its appearance in education, the bibliometric research has been conducted [67]. The bibliometric 
study is prepared by the authors based on data of the Scopus database. Bibliometric analysis was carried out on 30 April 2020. The authors used the following keywords-Spatial exploration, economic data, education.

The main technique within the bibliometric analysis is mapping, aimed at producing different bibliometric maps that provide an overview of the structure of scientific publications in a specific research field. One of the most popular ways to use bibliometric mapping is to identify specific research areas within a selected science field, with the specific purpose of getting a view of the size of the field and relevant subfields and how they relate to each other [68]. Visualization of Similarities (VOS) is the newest mapping technique and has been used to create bibliometric maps in various studies. This technique has been implemented in a computer program called VOSviewer and was used in our bibliometric analysis. To make a term-map based on a corpus of documents, VOSviewer software distinguishes the following steps [68,69]. Identification of noun phrases, selection of the most relevant noun phrases, mapping and clustering of the terms, visualization of the mapping and clustering results.

An analysis of the time series of published documents appearing in the cross-section of the three search keywords shows that their intertwining is increasingly important and that the number of documents is increasing, which indicates the topicality and interdisciplinary nature of this field, as presented by Figure 2 (data for 2020 are not included).

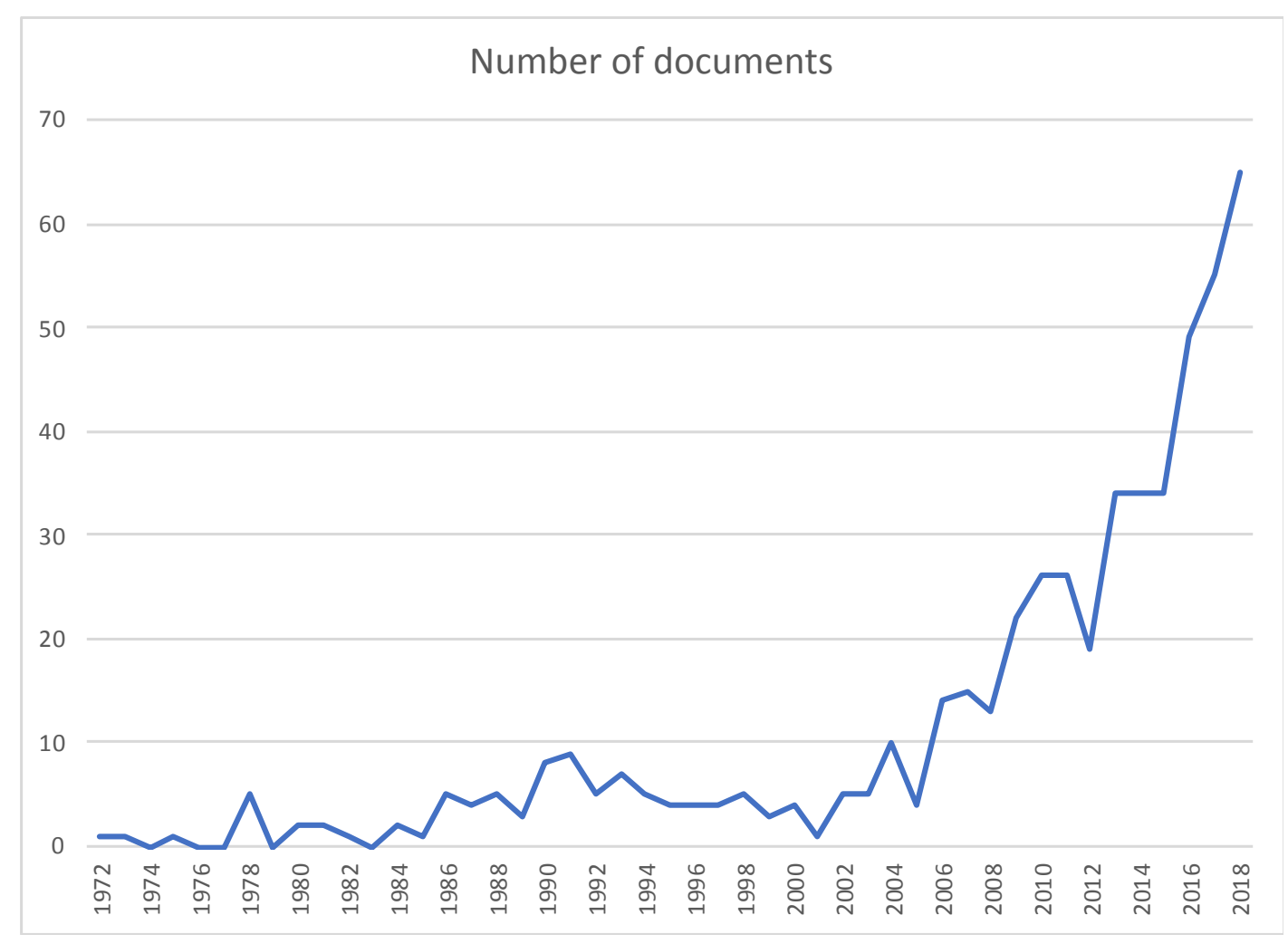

Figure 2. The time series of published items in the Scopus database, 30 April 2020, keywords spatial exploration, economic data, education. (Source: Authors' research, based on Scopus data).

The interdisciplinarity of the field of spatial exploration of economic data-spationomy-is also reflected in the variety of fields covered by the scientific publications in Scopus with the selected three keywords, as presented by Figure 3 . 


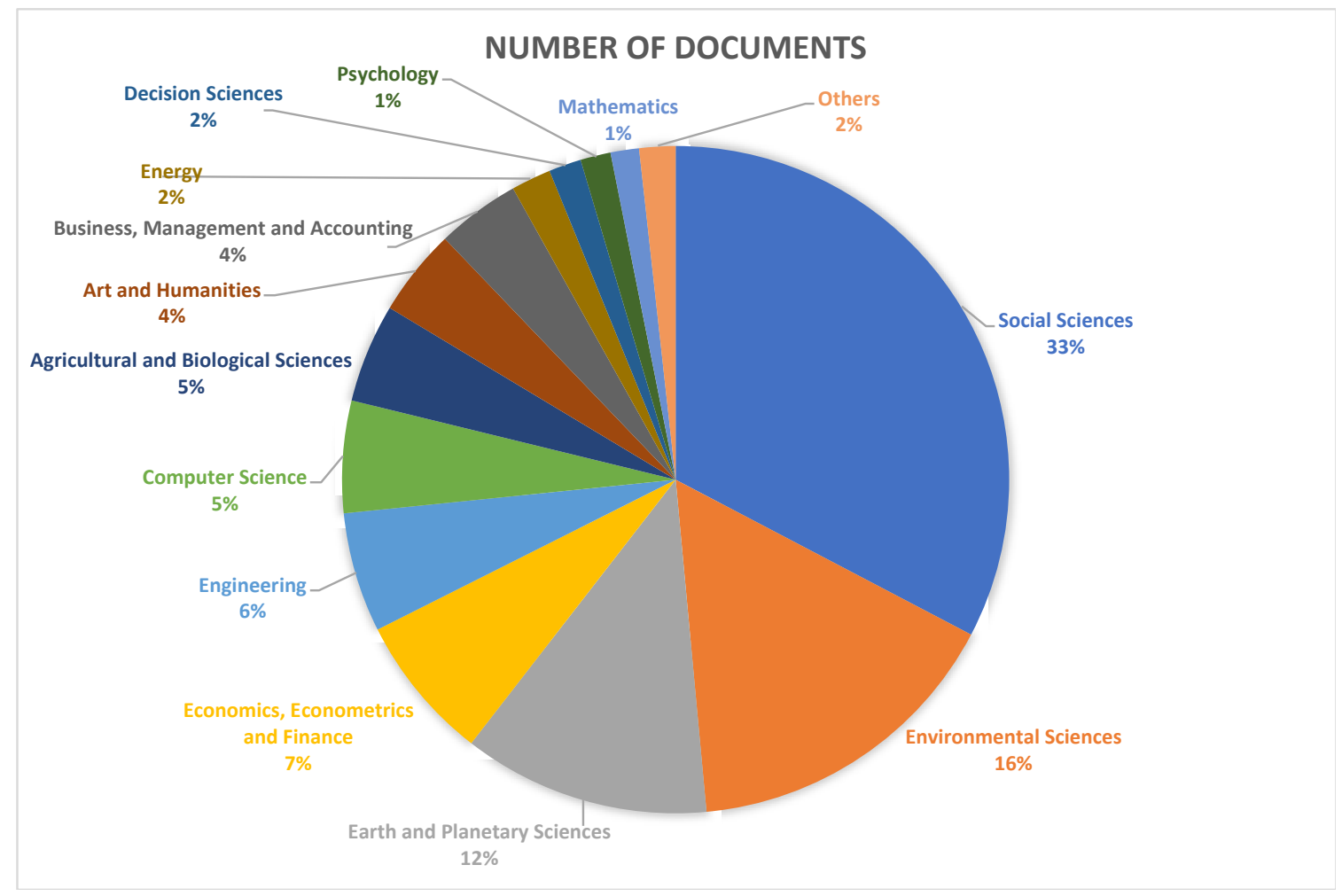

Figure 3. Structure of published items in the Scopus database, 30 April 2020, keywords spatial exploration, economic data, education, regarding the research area. (Source: Authors' research, based on Scopus data).

Bibliometric analysis with the time component (Figure 4) clearly shows that the importance of education in this interdisciplinary field in the post-2010 period is being highlighted in publications. At the same time, the increasingly interdisciplinary nature of research is identified, which extends from economic analysis to spatial analysis, GIS and digitalization (information systems, internet, etc.). At a time when spatial analysis of economic data was just beginning to emerge (right side of Figure 4), its main focus was more or less demographic statistics that addressed population and demographic characteristics.

The bibliometric analysis leads to the conclusion that the interdisciplinarity of the spationomy field is growing and is expanding very fast within higher education institutions. This is also indicated by the results of the research presented in Sections 3-7. 


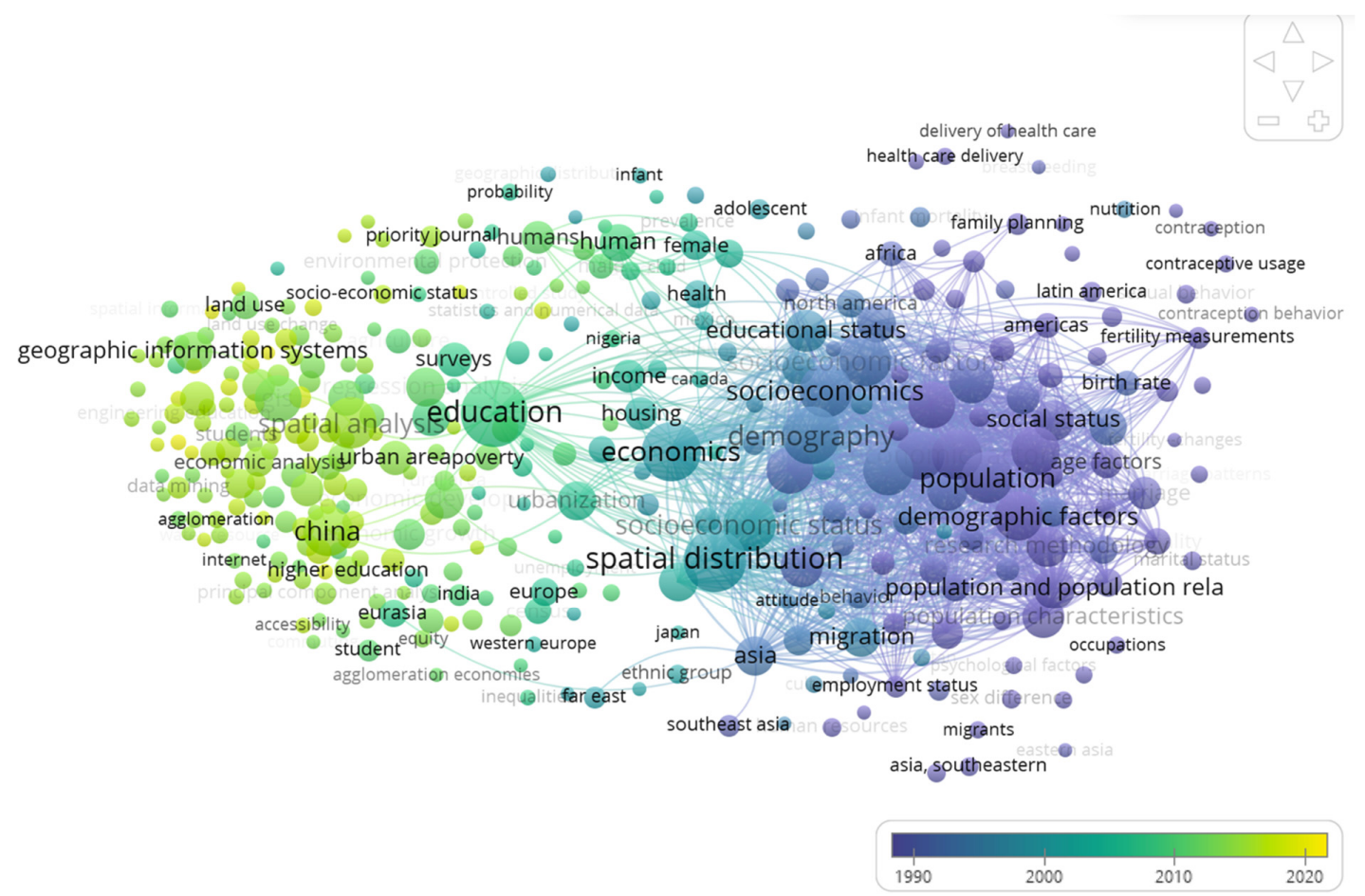

Figure 4. Bibliometric mapping with the time component analysis based on the Scopus database, 30 April 2020, keywords spatial exploration, economic data, education. (Source: Authors' research, based on Scopus data).

\section{Research Model}

The main goal of our research is to identify and compare the modified version of the model TAM proposed by Davis [15] and Davis et al. [16]. Initial TAM suggests that behavior is determined by the intent of the behavior to use it. Furthermore, the two central hypotheses in TAM state that perceived usefulness (PU) and perceived ease of use (PEOU) positively influence an individual's attitude toward the use of new technology (AT), which has a positive effect on his or her behavioral intention to use it (BI). In our research, the behavior refers to the future intention to use interdisciplinary knowledge of economics and geography. Further, an individual's attitude regarding use interdisciplinary knowledge of economics and geography and perceived usefulness of interdisciplinary knowledge of economics and geography jointly determine behavior intention to use it. On the other hand, perceived ease of use of interdisciplinary knowledge of economics and geography has an impact on perceived usefulness of interdisciplinary knowledge of economics and geography and on attitudes toward using it. We aim to identify and compare the significant effect on antecedents of students' attitude and future behavioral intention to use interdisciplinary knowledge of economics and geography for two groups (economic students and geography students). On that basis, we have developed the following null hypothesis:

Hypothesis 1. There are no differences in the strength of the relationships among constructs in the conceptual model between two researched groups of students (economic students and geography students) in two intersectional times-before they start to acquire interdisciplinary knowledge through the Spationomy project cycle and after the end of the project cycle.

We will test the null hypothesis by five research hypotheses presented below (H2-H6) that refer to the relationships among factors in the conceptual model for individual groups of students. If there are significant differences in the results, we will reject the null hypothesis and confirm the alternative hypothesis, which states that there are differences in the strength of the relationships of the research model between the two groups of students studied. We mainly used the initial TAM proposed by 
Davis [15] and Davis et al. [16] and extend factors items. In the case of the relationship between perceived ease of use (PEOU) and behavioral intention (BI), we followed recommendations of TAM 3 [45]. Our research model includes six hypotheses (Figure 5):

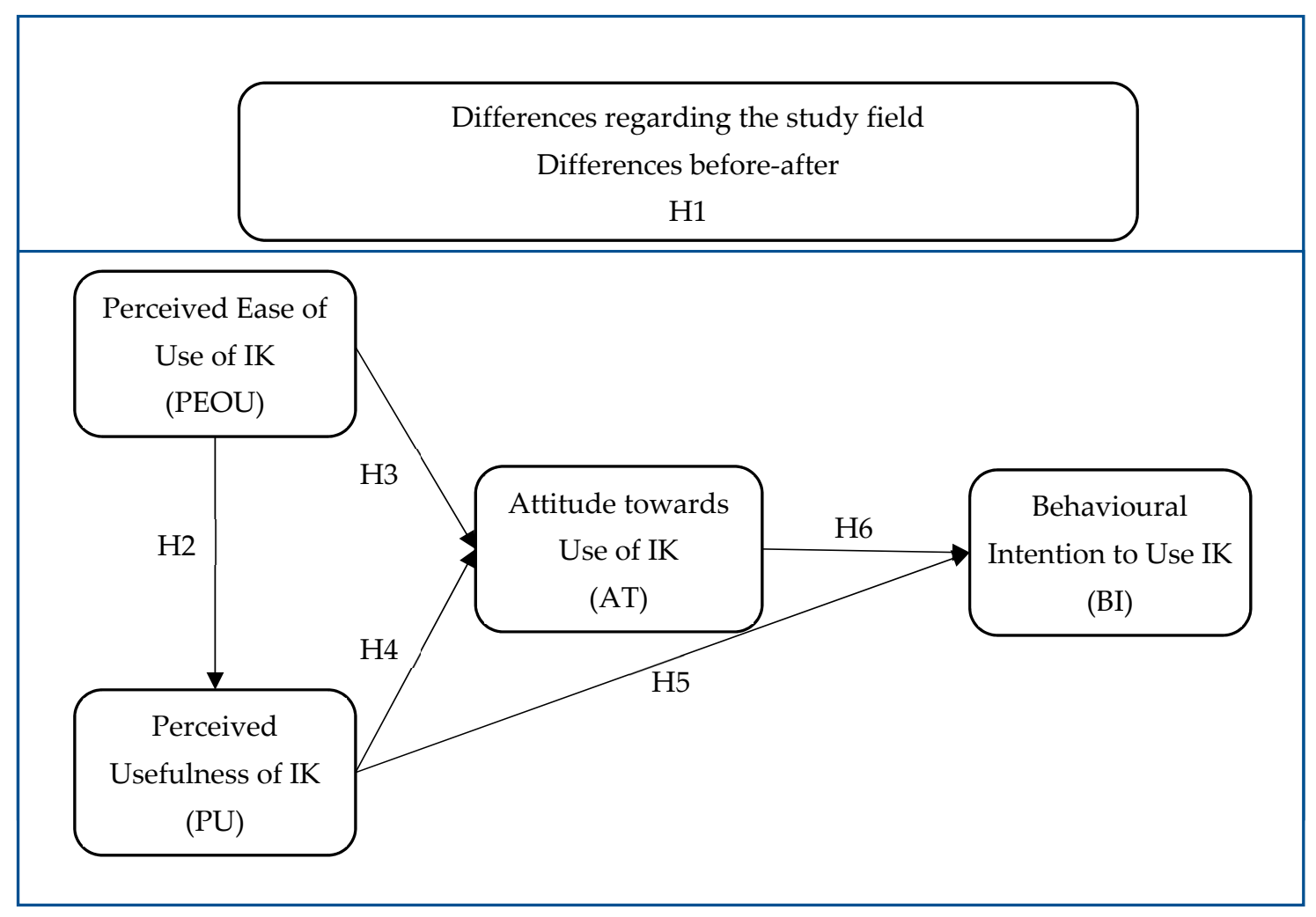

Figure 5. Conceptual model of research.

Hypothesis 2. Perceived ease of use of interdisciplinary knowledge of economics and geography (PEOU) has a positive direct effect on perceived usefulness of interdisciplinary knowledge (IK) of economics and geography (PU).

Hypothesis 3. Perceived ease of use of interdisciplinary knowledge (IK) of economics and geography (PEOU) has a positive direct effect on attitude toward the use of interdisciplinary knowledge of economics and geography (AT).

Hypothesis 4. Perceived usefulness of interdisciplinary knowledge (IK) of economics and geography (PU) has a positive direct effect on attitude toward the use of interdisciplinary knowledge of economics and geography (AT).

Hypothesis 5. Perceived usefulness of interdisciplinary knowledge (IK) of economics and geography (PU) has a positive direct effect on Behavior intention to use interdisciplinary knowledge of economics and geography (BI).

Hypothesis 6. Attitude toward the use of interdisciplinary knowledge (IK) of economics and geography (AT) has a positive direct effect on Behavior intention to use interdisciplinary knowledge of economics and geography (BI).

Through analyzing results, we will be able to answer the research question "Which factors have an impact on economic students' and geography students' attitude and behavior intention of interdisciplinary knowledge of economics and geography?"

In this paper, we want to research whether there are differences in research models between two groups of students (economics students, geography students), who have very different knowledge regarding economic and geography. Economics students know about economics and business but they do not have much knowledge regarding geography. On the other hand, geography students are 
familiar with the geography and they do not know about economics and business. We believe that there should be differences regarding the importance of behavior intention of using interdisciplinary knowledge of economics and geography for both groups. The effectiveness of encouraging students in both fields to adopt and use interdisciplinary knowledge in the Spationomy project was examined by analyzing differences in effects among components of the research model before students started to acquire interdisciplinary knowledge through the Spationomy project cycle and after the end of the project cycle.

Hypotheses presented are tested using the partial least squares (PLS) approach, which is one of the techniques of component-based structural equation modelling (SEM).

\section{Methodology}

The survey questionnaire was developed in three phases. In the first phase, we clarified the relationships between the constructs and the measurement scales for individual constructs, after we researched the literature and resources. A questionnaire with four measurement scales for measuring constructs of the model was employed. The items of constructs were based on Davis's prior research [15], with modifications to fit the specific context of the interdisciplinary knowledge and based on the studies of Letchumann and Muniandy [70], Park [71] and Šebjan and Tominc [72]. Four adjusted factors from the original TAM were included in the research model. We chose TAM because there were different software tools in the background of their interdisciplinary knowledge. The research design consists of the following constructs-perceived ease of use of interdisciplinary knowledge of economics and geography (PEOU; 4 items), perceived usefulness of interdisciplinary knowledge of economics and geography (PU; 6 items), attitude toward the use of interdisciplinary knowledge of economics and geography (AT; 4 items) and behavior (future) intention to use interdisciplinary knowledge of economics and geography (BI; 3 items). See Table 1 . All items in the questionnaire were scored on a 7-point Likert scale ranging from 1 (strongly disagree) to 7 (strongly agree). From the original TAM, we excluded external factors because we wanted to trace the impact of internal beliefs (PEOU and PU) on attitude (AT) and the intention to use it (BI). We also excluded the factor actual use (U), as the studied students were not able to use the acquired interdisciplinary knowledge in practice by the end of the Spationomy project. This could be measured only later when students would use the acquired interdisciplinary knowledge in their study and practice.

In the second phase, the instrument was tested with a group of 33 economics students. Based on the results of the pilot testing, revisions and additions were made to the instrument.

In the third phase, the survey was conducted. We collected data three years (2017-2019) before and at the end of Spationomy project round of all students (eco and geo) who participate in the Spationomy project. All students had completed the online questionnaire. Students were from a partner institution in the Spationomy Erasmus+ project-from two economics/business-oriented departments (Moravian University College Olomouc, the Czech Republic and the University of Maribor, the Republic of Slovenia) and two geo-oriented departments (Palacký University Olomouc, the Czech Republic and the Rhur University of Bochum, Germany). We collected 37 answers of economic/business-oriented students (EcoBe) and 44 answers of geo-oriented students (GeoBe) at the beginning of the project cycle and 40 answers of economic/business-oriented students (EcoAf) and 40 answers of geo oriented students (GeoAf) at the end of the project cycle. There were no statistical differences between groups per year. Respondents were $48 \%$ male and $52 \%$ female; $67 \%$ of students were Bachelor cycle students and 33\% were Master students. Regarding the cycle of the Spationomy project, $36 \%$ participated in 2017, 32.9\% in 2018 and $31.1 \%$ in 2019 . 
Table 1. Constructs of the research model.

\begin{tabular}{|c|c|}
\hline Factor & Items \\
\hline PEOU & $\begin{array}{l}\text { PEOU1: Integration of interdisciplinary knowledge of economics and geography is simple } \\
\text { and easy to understand. } \\
\text { PEOU2: Learning and obtaining the interdisciplinary knowledge of economics and } \\
\text { geography is simple. } \\
\text { PEOU3: Integration of interdisciplinary knowledge of economics and geography is simple. } \\
\text { PEOU4: I think it is easy to integrate the interdisciplinary knowledge of economics and } \\
\text { geography with the purpose to obtain the desired results. }\end{array}$ \\
\hline PU & $\begin{array}{l}\text { PU1: Using an interdisciplinary knowledge of economics and geography enables me to } \\
\text { accomplish learning activities and obligations more quickly. } \\
\text { PU2: Using an interdisciplinary knowledge of economics and geography helps me } \\
\text { accomplish my studying effectively. } \\
\text { PU3: Interdisciplinary knowledge of economics and geography is beneficial knowledge. } \\
\text { PU4: Interdisciplinary knowledge of economics and geography enables me to accomplish } \\
\quad \text { learning obligations more easily. } \\
\text { PU5: In my opinion, expertise obtained regarding interdisciplinary knowledge of } \\
\text { economics and geography at faculty, is useful in general. } \\
\text { PU6: In my opinion usage of interdisciplinary knowledge of economics and geography } \\
\text { should be learned in all schools of economics and business/geography of higher education. }\end{array}$ \\
\hline $\mathrm{AT}$ & $\begin{array}{l}\text { AT1: Overall, I have a positive opinion about the use of interdisciplinary knowledge of } \\
\text { economics and geography. } \\
\text { AT2: I believe it is a good idea to apply the interdisciplinary knowledge of economics and } \\
\text { geography while studying. } \\
\text { AT3: I like the idea about the integration and use of interdisciplinary knowledge of } \\
\text { economics and geography. } \\
\text { AT4: I support the integration and use of interdisciplinary knowledge of economics } \\
\text { and geography. }\end{array}$ \\
\hline BI & $\begin{array}{l}\text { BI1: I will try to obtain even more interdisciplinary knowledge of economics and } \\
\text { geography in the future. } \\
\text { BI2: I will use interdisciplinary knowledge of economics and geography more often in } \\
\text { the future. } \\
\text { BI3: I will share my knowledge of interdisciplinary knowledge of economics and } \\
\text { geography and recommend others to use it. }\end{array}$ \\
\hline
\end{tabular}

The parameters in a hierarchical model can be estimated through covariance-based structural equation modelling (SEM) or component-based SEM, also known as partial least squares (PLS) approach. In our research model (see Figure 5) factor perceived ease of use of interdisciplinary knowledge (PEOU) have influences on factor perceived usefulness of interdisciplinary knowledge (PU) and on factor attitude toward the use of interdisciplinary knowledge (AT). Factor perceived usefulness of interdisciplinary knowledge (PU) and factor attitude towards the use of interdisciplinary knowledge (AT) have an impact on factor behavioral intention to use interdisciplinary knowledge (BI).

PLS has several advantages $[51,72,73]$ — it is a predictive technique suitable for cases with less theoretical development; minimum requirements for measuring scales; it avoids problems with factor uncertainty and inadmissible solutions; do not make any assumptions about the data; avoids identification problems with recursive models; it does not require special distributions for the measured variables; works well with small samples; and so forth. Because the research area of acceptance of the use of interdisciplinary knowledge of economics and geography through TAM and comparison of groups with small samples (around 40 answers per group), the PLS technique was selected. In the first phase, all measurement scales were checked for their psychometric properties and in the second phase, the focus was on testing and analyzing hypotheses.

Statistical Package for the Social Sciences (SPSS), Microsoft Excel and SmartPLS 3 [74] software tools were used. 


\section{Results and Analysis}

\subsection{Measurement Model}

In the first step, the measurement model was assessed. Psychometric properties (measurement model) of these scales were assessed via evaluation of reliability, convergent validity and discriminant validity of each measurement scale. For factor loadings of indicators, criteria higher than the value of 0.7 were used [74-76] (Table 2). Composite reliabilities assessed the reliability of model measurement fit for constructs where criteria equal to or greater than 0.6 were used [73] and by Cronbach's alphas $(\alpha)$ that also describe convergent validity and should be equal to or greater than 0.6 [77]. As shown in Table 3, each of our four scales had Cronbach's alpha exceeding 0.85 and composite reliability exceeding 0.90 , thus assuring adequate construct reliability for our measurement scales.

Table 2. Descriptive statistics for four groups.

\begin{tabular}{llllllllllllll}
\hline Groups & \multicolumn{3}{c}{ EcoBe } & \multicolumn{3}{c}{ EcoAf } & \multicolumn{3}{c}{ GeoBe } & \multicolumn{3}{c}{ GeoAf } \\
\hline Items & Aver. & St.dev. & Load. & Aver. & St.dev. & Load. & Aver. & St.dev. & Load. & Aver. & St.dev. & Load. \\
\hline PEOU1 & 4.757 & 1.234 & 0.898 & 4.525 & 1.261 & 0.908 & 4.636 & 1.014 & 0.870 & 5.075 & 1.118 & 0.872 \\
PEOU2 & 4.432 & 1.259 & 0.890 & 4.275 & 1.281 & 0.928 & 4.295 & 1.173 & 0.834 & 4.450 & 1.300 & 0.871 \\
PEOU3 & 4.135 & 1.206 & 0.903 & 4.325 & 1.141 & 0.946 & 4.409 & 1.064 & 0.836 & 4.750 & 1.056 & 0.877 \\
PEOU4 & 4.324 & 1.334 & 0.910 & 4.500 & 1.377 & 0.866 & 4.409 & 1.106 & 0.800 & 4.775 & 1.387 & 0.824 \\
PU1 & 5.135 & 1.084 & 0.801 & 4.950 & 1.239 & 0.814 & 5.000 & 1.161 & 0.791 & 5.350 & 1.312 & 0.846 \\
PU2 & 4.973 & 1.118 & 0.741 & 4.975 & 1.187 & 0.885 & 5.023 & 1.023 & 0.791 & 5.100 & 1.336 & 0.835 \\
PU3 & 5.757 & 1.140 & 0.894 & 5.600 & 1.297 & 0.903 & 5.864 & 1.391 & 0.869 & 6.175 & 1.130 & 0.827 \\
PU4 & 4.919 & 1.064 & 0.767 & 4.950 & 1.176 & 0.864 & 4.886 & 1.298 & 0.759 & 5.250 & 1.127 & 0.846 \\
PU5 & 5.676 & 1.156 & 0.866 & 5.400 & 1.317 & 0.816 & 5.773 & 1.236 & 0.827 & 6.000 & 1.038 & 0.688 \\
PU6 & 5.027 & 1.424 & 0.818 & 4.925 & 1.492 & 0.728 & 5.386 & 1.558 & 0.773 & 5.475 & 1.301 & 0.635 \\
AT1 & 5.892 & 1.430 & 0.885 & 5.450 & 1.260 & 0.841 & 6.045 & 1.056 & 0.914 & 6.150 & 1.210 & 0.940 \\
AT2 & 5.568 & 1.555 & 0.932 & 5.700 & 1.224 & 0.882 & 6.136 & 1.193 & 0.906 & 6.350 & 1.122 & 0.924 \\
AT3 & 5.973 & 1.343 & 0.958 & 5.700 & 1.324 & 0.924 & 6.091 & 1.254 & 0.922 & 6.200 & 1.181 & 0.925 \\
AT4 & 5.703 & 1.392 & 0.920 & 5.825 & 1.217 & 0.914 & 6.045 & 1.140 & 0.901 & 6.125 & 1.202 & 0.896 \\
BI1 & 5.054 & 1.508 & 0.830 & 5.050 & 1.395 & 0.915 & 4.932 & 1.189 & 0.892 & 5.325 & 1.492 & 0.939 \\
BI2 & 5.108 & 1.505 & 0.831 & 4.925 & 1.228 & 0.933 & 5.182 & 0.995 & 0.763 & 5.350 & 1.331 & 0.941 \\
BI3 & 5.216 & 1.475 & 0.860 & 4.900 & 1.172 & 0.858 & 5.318 & 1.157 & 0.787 & 5.550 & 1.552 & 0.910 \\
\hline
\end{tabular}

Table 3. Constructs' reliability and validity.

\begin{tabular}{ccccccccccccc}
\hline Groups & \multicolumn{3}{c}{ EcoBe } & \multicolumn{3}{c}{ EcoAf } & \multicolumn{3}{c}{ GeoBe } & \multicolumn{3}{c}{ GeoAf } \\
\hline Constructs & $\boldsymbol{\alpha}^{\mathbf{1}}$ & $\boldsymbol{C R}$ & $\boldsymbol{A V E}$ & $\boldsymbol{\alpha}^{\mathbf{1}}$ & $\boldsymbol{C R}$ & AVE & $\boldsymbol{\alpha}^{\mathbf{1}}$ & $\boldsymbol{C R}$ & $\boldsymbol{A V E}$ & $\boldsymbol{\alpha}^{\mathbf{1}}$ & $\boldsymbol{C R}$ & AVE \\
\hline PEOU & 0.922 & 0.945 & 0.811 & 0.933 & 0.952 & 0.833 & 0.858 & 0.902 & 0.698 & 0.884 & 0.920 & 0.742 \\
PU & 0.900 & 0.923 & 0.666 & 0.913 & 0.933 & 0.700 & 0.890 & 0.915 & 0.644 & 0.871 & 0.904 & 0.615 \\
AT & 0.943 & 0.959 & 0.854 & 0.913 & 0.939 & 0.793 & 0.932 & 0.951 & 0.830 & 0.941 & 0.957 & 0.849 \\
BI & 0.803 & 0.878 & 0.706 & 0.886 & 0.929 & 0.815 & 0.748 & 0.856 & 0.666 & 0.922 & 0.951 & 0.865 \\
\hline
\end{tabular}

${ }^{1}$ Note: $\alpha$-Cronbach's Alpha; $C R$-Composite Reliability; AVE—Average Variance Extracted.

Fornell and Larcker's [78] assessment criteria were adopted for convergent validity. All item factor loadings should be significant and should exceed 0.70 and the average variance extracted (AVE) for each construct should exceed 0.50 [76,77]. Table 2 lists item factor loadings, all of which were significant at $p<0.001$ and were higher than the recommended level of 0.70; all values AVE exceeded 0.50 as well (Table 3). The remainder of our measurement scales shows strong evidence for convergent validity.

Discriminant validity between constructs was assessed following Fornell and Larcker's [78] recommendation that the square root of AVE for each construct should exceed the bivariate correlations between that construct and all other constructs. The inter-construct correlation matrix (Table 4) shows that the principal diagonal elements (square root AVE) exceed non-diagonals elements in the same row or columns (bivariate correlations), demonstrating that the discriminate validity of all 
scales is also adequate. Discriminant validities were also accessed by the Heterotrait-Monotrait Ratio (HTMT) [76,77,79] with HTMT ratio being below 1, while stricter cut-off of 0.85 has been used in previous research [80]. All HTMT ratio results are below 1 confirming the discriminant validity.

Table 4. The Fornell-Larcker criterion and the variables' correlation matrix and the Heterotrait-Monotrait (HTMT) Ratio.

\begin{tabular}{|c|c|c|c|c|c|c|c|c|}
\hline \multirow{2}{*}{$\begin{array}{l}\text { Groups } \\
\text { Constructs }\end{array}$} & \multicolumn{4}{|c|}{ EcoBe } & \multicolumn{4}{|c|}{ EcoAf } \\
\hline & PEOU & PU & $\mathrm{AT}$ & BI & PEOU & PU & $\mathrm{AT}$ & BI \\
\hline PEOU & 0.900 & & & & 0.912 & & & \\
\hline \multirow{2}{*}{ PU } & 0.437 & 0.816 & & & 0.578 & 0.837 & & \\
\hline & 0.475 & & & & 0.626 & & & \\
\hline AT & 0.270 & 0.727 & 0.924 & & 0.450 & 0.786 & 0.891 & \\
\hline \multirow{5}{*}{ BI } & 0.200 & & & & 0.483 & 0.050 & & \\
\hline & 0.205 & 0.573 & 0.637 & 0.840 & 0.392 & 0.660 & 0.800 & 0.903 \\
\hline & 0.260 & 0.632 & 0.666 & & 0.425 & 0.725 & 0.886 & \\
\hline & \multicolumn{4}{|c|}{ GeoBe } & \multicolumn{4}{|c|}{ GeoAf } \\
\hline & PEOU & PU & AT & BI & PEOU & PU & $\mathrm{AT}$ & BI \\
\hline PEOU & 0.835 & & & & 0.861 & & & \\
\hline \multirow{2}{*}{ PU } & 0.303 & 0.802 & & & 0.510 & 0.784 & & \\
\hline & 0.320 & & & & 0.572 & & & \\
\hline \multirow{2}{*}{ AT } & 0.375 & 0.763 & 0.911 & & 0.552 & 0.838 & 0.921 & \\
\hline & 0.417 & 0.816 & & & 0.594 & 0.918 & & \\
\hline \multirow{2}{*}{ BI } & 0.202 & 0.644 & 0.569 & 0.816 & 0.522 & 0.735 & 0.664 & 0.930 \\
\hline & 0.251 & 0.771 & 0.676 & & 0.561 & 0.823 & 0.705 & \\
\hline
\end{tabular}

Note: HTMT ratio-italic text.

The model adaptation was assessed by the standardized root mean square residual (SRMS). The model fits well when SRMS is lower than 0.10 [77,79], while some use a stricter cut-off lower than 0.08 [81]. Our models have SRMS (EcoBe) is 0.10, SRMS (EcoAf) is 0.074, SRMS (GeoBe) is 0.094 and SRMS (GeoAf) is 0.093 , which are acceptable for the preliminary models.

\subsection{Structural Model and Hypotheses Testing}

Structural path coefficients (loadings-standardized regression coefficients) were analyzed using the significance level at 0.05 . $R^{2}$ and Adjusted $R^{2}$ were used to measure the total magnitude of the effect size for the structural equation model, with the results above the cut-offs of $0.67,0.33$ and 0.19 being substantial, moderate and weak, respectively [73]. From Table 5 we can see that Behavior Intention (BI), which is a primary outcome measure of the model, has a close to substantial $R^{2}$, from 0.432 at the beginning to 0.642 after for economic students and from 0.429 at the beginning to 0.523 after for geography students. Attitude toward using it (AT) is also high, from 0.532 at the beginning to 0.617 after for economic students and 0.604 at the beginning to 0.708 after for geography students. Perceived usefulness is weak 0.191 at the beginning and moderates with 0.334 after for economic students, no effect with 0.092 at the beginning and week effect with 0.260 after for geography students. We can conclude that the structural model demonstrates predictive power as the variance explained $\left(R^{2}\right)$ in key endogenous constructs. 
Table 5. The goodness of fit for the structural model through.

\begin{tabular}{|c|c|c|c|c|c|c|c|c|}
\hline \multirow{2}{*}{$\begin{array}{l}\text { Groups } \\
\text { Constructs }\end{array}$} & \multicolumn{2}{|c|}{ EcoBe } & \multicolumn{2}{|c|}{ EcoAf } & \multicolumn{2}{|c|}{ GeoBe } & \multicolumn{2}{|c|}{ GeoAf } \\
\hline & $R^{2}$ & Adj. $R^{2}$ & $R^{2}$ & $\operatorname{Adj.} R^{2}$ & $R^{2}$ & Adj. $R^{2}$ & $R^{2}$ & Adj. $R^{2}$ \\
\hline \multicolumn{9}{|l|}{ PEOU } \\
\hline PU & 0.191 & 0.168 & 0.334 & 0.316 & 0.092 & 0.070 & 0.260 & 0.241 \\
\hline AT & 0.532 & 0.504 & 0.617 & 0.597 & 0.604 & 0.585 & 0.723 & 0.708 \\
\hline BI & 0.431 & 0.398 & 0.642 & 0.623 & 0.429 & 0.401 & 0.548 & 0.523 \\
\hline
\end{tabular}

Note: $R^{2}$-R square; Adj. $R^{2}$-Adjusted R square.

Statistically significant relationships among the constructs were tested for hypotheses $\mathrm{H} 2-\mathrm{H} 6$ for each group of students. Path significance and magnitude of each of our hypothesized effects and the overall explanatory power of the proposed model were examined. The hypotheses testing results are based on bootstrapping with 500 subsamples to test the statistical significance of each path coefficient using t-test recommended by Chin [73]. Results of this analysis are shown in Table 6 and Figure 5 . In Table 6, the significant path coefficients are presented (original sample and sample mean), along with standard error and t-statistics.

Table 6. Results of structural model analysis 1,2 .

\begin{tabular}{|c|c|c|c|c|c|c|c|c|c|c|}
\hline Relationship & $\beta$ & $\beta^{\prime}$ & $\begin{array}{l}\text { EcoBe } \\
\text { St.r. }\end{array}$ & $t$ & $p$ & $\beta$ & $\beta^{\prime}$ & $\begin{array}{l}\text { EcoAf } \\
\text { St.r. }\end{array}$ & $t$ & $p$ \\
\hline $\mathrm{PEOU} \rightarrow \mathrm{PU}$ & 0.437 & 0.446 & 0.142 & 3.081 & $0.002 *$ & 0.578 & 0.585 & 0.087 & 6.666 & $0.000 * *$ \\
\hline $\mathrm{PEOU} \rightarrow \mathrm{AT}$ & -0.059 & -0.022 & 0.186 & 0.318 & 0.750 & -0.006 & -0.014 & 0.131 & 0.049 & 0.961 \\
\hline $\mathrm{PU} \rightarrow \mathrm{AT}$ & 0.753 & 0.748 & 0.098 & 7.715 & $0.000 * *$ & 0.789 & 0.795 & 0.139 & 5.699 & $0.000 * *$ \\
\hline $\mathrm{PU} \rightarrow \mathrm{BI}$ & 0.233 & 0.229 & 0.288 & 0.810 & 0.418 & 0.083 & 0.068 & 0.154 & 0.538 & 0.590 \\
\hline \multirow[t]{2}{*}{$\mathrm{AT} \rightarrow \mathrm{BI}$} & 0.467 & 0.470 & 0.291 & 1.605 & 0.108 & 0.735 & 0.750 & 0.123 & 5.969 & $0.000 * *$ \\
\hline & \multicolumn{5}{|c|}{ GeoBe } & \multicolumn{5}{|c|}{ GeoAf } \\
\hline Relationship & $\beta$ & $\beta^{\prime}$ & St.r. & $t$ & $p$ & $\beta$ & $\beta^{\prime}$ & St.r. & $t$ & $p$ \\
\hline $\mathrm{PEOU} \rightarrow \mathrm{PU}$ & 0.303 & 0.320 & 0.156 & 1.939 & 0.053 & 0.510 & 0.493 & 0.174 & 2.928 & $0.003 *$ \\
\hline $\mathrm{PEOU} \rightarrow \mathrm{AT}$ & 0.159 & 0.166 & 0.120 & 1.321 & 0.186 & 0.168 & 0.154 & 0.112 & 1.501 & 0.133 \\
\hline $\mathrm{PU} \rightarrow \mathrm{AT}$ & 0.715 & 0.706 & 0.089 & 8.070 & $0.000 * *$ & 0.752 & 0.744 & 0.079 & 9.564 & $0.000 * *$ \\
\hline $\mathrm{PU} \rightarrow \mathrm{BI}$ & 0.502 & 0.503 & 0.146 & 3.441 & $0.001 *$ & 0.600 & 0.588 & 0.177 & 3.382 & $0.001 *$ \\
\hline $\mathrm{AT} \rightarrow \mathrm{BI}$ & 0.186 & 0.198 & 0.143 & 1.301 & 0.193 & 0.161 & 0.164 & 0.185 & 0.872 & 0.383 \\
\hline
\end{tabular}

From Figure 6 and Table 6 we can see, that factor perceived ease of use of interdisciplinary knowledge of economics and geography (PEOU) has a positive direct effect on perceived usefulness of interdisciplinary knowledge of economics and geography (PU) for three groups-economic students at the beginning $(\beta=0.44, p<0.001)$, economic students at the end $(\beta=0.58, p<0.001)$ and geography students at the end $(\beta=0.51, p<0.001)$, while for geography students at the beginning this relationship is not statistically significant $(\beta=0.30, p>0.001)$. Hypothesis $\mathrm{H} 2$ can be partially confirmed. Further, factor PEOU has no statistical effect on attitudes toward using it (AT) for all groups, so we cannot confirm hypothesis H3 (EcoBe: $\beta=-0.06, p>0.01$; EcoAf: $\beta=-0.01, p>0.01$; GeoBe: $\beta=0.16, p>0.01$; GeoAf: $\beta=-0.17, p>0.01$ ). Factor perceived usefulness of interdisciplinary knowledge of economics and geography (PU) has a positive direct effect on attitudes toward the use of interdisciplinary knowledge of economics and geography (AT) for all four groups (EcoBe: $\beta=0.75, p<0.001$; EcoAf: $\beta=0.79$, $p<0.001$; GeoBe: $\beta=0.71, p<0.001$; and GeoAf: $\beta=0.74, p<0.001$ ), so we can confirm hypothesis $\mathrm{H} 4$. Factor perceived usefulness of interdisciplinary knowledge of economics and geography (PU) has a positive direct effect on behavior intention to use interdisciplinary knowledge of economics and geography (BI) for geography students (GeoBe: $\beta=0.50, p<0.001$; and GeoAf: $\beta=0.59, p<0.001$ ), while not for economic students (EcoBe: $\beta=0.23, p>0.01$; and EcoAf: $\beta=0.08, p>0.01$ ). We can partly confirm hypothesis H5. Hypothesis $\mathrm{H} 5$ can be partly confirmed as well because attitudes toward the use of interdisciplinary knowledge of economics and geography (AT) have a strong positive 
direct effect on behavior intention to use interdisciplinary knowledge of economics and geography (BI) only for the group of economic students at the end (EcoAf: $\beta=0.74, p<0.001$ ). Due to the above-mentioned differences, hypothesis $\mathrm{H} 0$ can be rejected. There is a significant difference between two groups (economic students and geography students) regarding relationships and their significance in our research model.
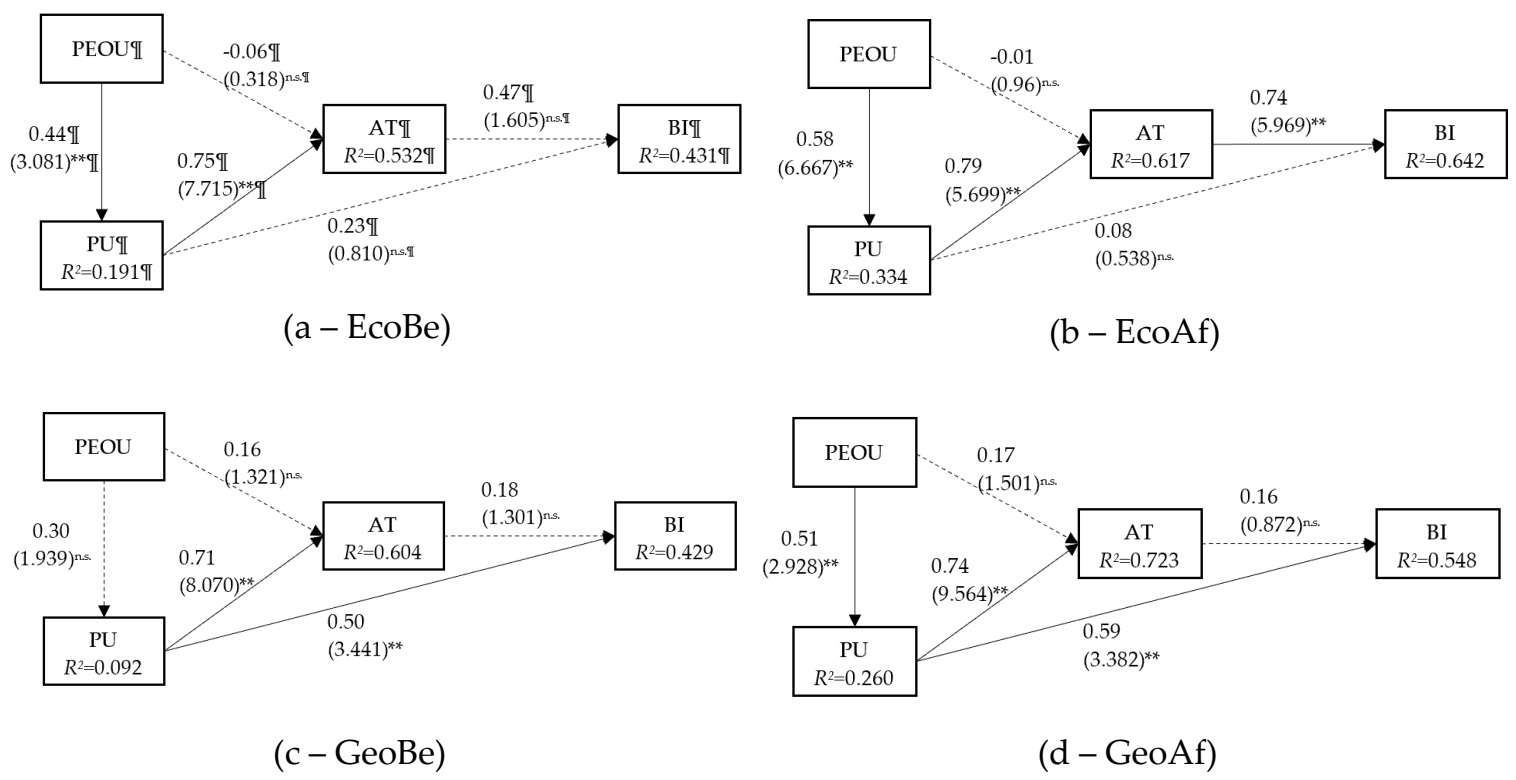

Figure 6. (a) Results of structural model analysis for economic students at the beginning; (b) Results of structural model analysis for economic students at the end; (c) Results of structural model analysis for geography students at the beginning; (d) Results of structural model analysis for geography students at the end.

\section{Discussion}

At the beginning of the Spationomy project, students were "new users" of interdisciplinary knowledge, about which they had different prior knowledge. Economic students were familiar with some tools in the field of business information systems and personal computer use tools (e.g., Microsoft Office), while geography students were primarily familiar with geographic information systems (GIS). None of the students, however, had in-depth interdisciplinary economic and spatial knowledge. The research conducted reveals that there are differences between the four studied groups of students (EcoBe, EcoAf, GeoBe and GeoAf).

Some authors argue that perceived ease of use (PEOU) appears to be more important during initial phases and is becoming less important over time of use [16]. Davis and Bala [45] further suggested that with increased experience, the impact of perceived ease of use (PEOU) (they named it "low-level identity") on perceived usefulness (PU) (they called it "high-level identity") will be stronger, if users will assess that the achievement of higher goals (i.e., PU—-perceived usefulness) based on information obtained from the experience of achieving lower goals (i.e., PEOU—perceived ease of use) is easier.

Our research shows that the link between perceived ease of use (PEOU) and perceived usefulness (PU) (Hypothesis H2) for economic students is important from the beginning (EcoBe; $\beta=0.44$ ) but not for geography students (GeoBe; $\beta=0.30$ ). After the end of the Spationomy project cycle, this connection is even more important for economists (EcoAf; $\beta=0.58$ ) but it also becomes statistically significant for geography students (GeoAf; $\beta=0.51$ ). Through the project, the students found that they would find it easier to achieve the higher system goals of the perceived usefulness (PU) with increased experience of perceived ease of use (PEOU). Perhaps this has to do with the study field of the social sciences and social sciences students profile; maybe we can speculate that perceived ease of use (PEOU) is therefore important to social science students from the beginning and that it then affects 
perceived usefulness (PU). This can be confirmed both by the present research and by research by other authors [58,82], where the authors investigated the acceptance of learning business information system at the beginning and the end on a sample of economic students. In both mentioned research, the cited authors had found that the relationship between perceived ease of use (PEOU) and perceived usefulness (PU) is statistically significant. We can also speculate that geography students are more adept at various difficult IT/IS programs and that they therefore initially perceived the perceived ease of use (PEOU) to not be important. This is also consistent with findings of Adu Gyamfi [65], who researched extended TAM to examine factors that have influence the acceptance of Web 2.0 technologies for the pedagogical purpose of geography students, future teachers, from Ghana, based on 254 answers. The results showed that technological complexity, perceived usefulness and attitude towards use had a significant direct effect on the intention to use Web 2.0 technologies. Besides, he found out that perceived ease of use had no significant influence on perceived usefulness. Similar results also found Lay et al. [60], based on 725 senior high school teachers of geography. This is in line with our recognitions. Through the Spationomy project, however, geography students found out that the complexity of the interdisciplinary knowledge is high. Therefore, after the end of the project cycle, this connection becomes statistically significant. We perceive this as their realization of the basics of systems theory in practice.

Our assumptions are also confirmed by the relationship between perceived ease of use (PEOU) and attitude toward use (AT) (Hypothesis H3), which is not statistically significant in any of the four models studied (EcoBe, EcoAf, GeoBe and GeoAF). This means that perceived ease of use (PEOU) does not affect attitude towards use (AT) in any case. Only when students perceive the usefulness of the interdisciplinary knowledge based on experience (perceived ease of use-PEOU), the so-called "high-level identity," does attitude towards using it (AT) become very important (Hypothesis H4). All four models studied show that this connection is statistically significant (EcoBe: $\beta=0.75$; EcoAf: $\beta=0.79$; GeoBe: $\beta=0.71$; GeoAf: $\beta=0.74$ ). This is consistent with the above-mentioned research $[58,60,65,82]$. Moreover, at the end of the Spationomy project cycle, based on the experience gained, it is more strongly important.

The link between perceived usefulness (PU) to behavioral intention (BI) (Hypothesis H5) in the case of economy students was not significant at the beginning of the Spationomy project cycle (EcoBe) neither directly (perceived usefulness-PU on behavioral intention-BI; $\beta=0.23$ ) nor indirectly (through attitude toward use-AT on behavioral intention-BI; $\beta=0.47$ ). At the end of the Spationomy project cycle (EcoAf), this connection is indirectly highly important $(\beta=0.74)$ via attitude toward use (AT) (Hypothesis H6). Geography students, on the contrary, found a direct link between perceived usefulness (PU) and behavioral intention (BI) important already at the beginning of the Spationomy project $(\mathrm{GeoBe} ; \beta=0.50)$ but there is no indirect effect of perceived usefulness (PU) on behavioral intention (BI) via attitude toward use (AT). At the end of the Spationomy project, for geography students (GeoAf), the direct link between perceived usefulness (PU) and behavioral intention (BI) is even stronger than at the beginning $(\beta=0.59)$. Also, this is in line with recognitions of Adu Gyamfi [65]. Furthermore, in TAM3 by Venkatesh and Bala [45] authors "found that perceived usefulness was the strongest predictor of behavioral intention at all time periods," for example, in all time intervals.

Venkatesh and Bala [45] found out that the TAM consistently explained approximately $40 \%$ of the variance of an individual's behavioral intention of use (BI) and added, that this is also consistent with much prior research on IT/IS adoption and social psychology. In our research, it turned out that this variance in the initial model is equal to $43.1 \%$ for economy students (EcoBe) and $42.9 \%$ for geography students (GeoBe), while the variance at the end of the project cycle for economic students (EcoAf) is even $64.2 \%$, for geography students (GeoAf) it is $54.8 \%$. If we calculate average exploratory power of variance of the research model of Spationomy project students at the beginning of the learning process, it has for economic students (EcoBe) average $\mathrm{R}^{2}=0.385$ and for geography students (GeoBe) average $R^{2}=0.375$. At the end of the learning process of Spationomy project cycle, these powers of variance were higher, with average $R^{2}=0.531$ for economic students (EcoAf) and average $R^{2}=0.510$ 
for geography students (GeoAf). That means that more than $50 \%$ of the variance of the research model is explained. These findings (Table 7) are also in line with the previously cited TAM research and confirm the quality of our research.

Table 7. Confirmation of hypotheses.

\begin{tabular}{|c|c|c|c|c|c|}
\hline Hypotheses & EcoBe & EcoAf & GeoBe & GeoAf & Confirmation \\
\hline Null hypothesis & & & & & rejected \\
\hline $\mathrm{H} 2: \mathrm{PEOU} \rightarrow \mathrm{PU}$ & $\checkmark$ & $\checkmark$ & $x$ & $\checkmark$ & partially confirmed \\
\hline H3: $\mathrm{PEOU} \rightarrow \mathrm{AT}$ & $x$ & $x$ & $x$ & $x$ & rejected \\
\hline $\mathrm{H} 4: \mathrm{PU} \rightarrow \mathrm{AT}$ & $\checkmark$ & $\checkmark$ & $\checkmark$ & $\checkmark$ & confirmed \\
\hline $\mathrm{H} 5: \mathrm{PU} \rightarrow \mathrm{BI}$ & $x$ & $x$ & $\checkmark$ & $\checkmark$ & partially confirmed \\
\hline H6: $\mathrm{AT} \rightarrow \mathrm{BI}$ & $x$ & $\checkmark$ & $x$ & $x$ & partially confirmed \\
\hline
\end{tabular}

\section{Conclusions}

With this research, we confirmed that it is possible to implement the TAM to investigate the acceptance of the use of interdisciplinary knowledge of economic and geography students in the learning process, analyzing factors of the original TAM. This is consistent with the claims of the authors of the TAM Davis [15] and Davis et al. [16] and newer versions of TAM 2 [40] and TAM 3 [45], who argue that TAM can be applied to different applications of the technology. This is also confirmed by the findings of the authors Tominc et al. [4], where a sample of ninety-nine economic and geography students was randomly selected in 2017, before the start of the Spationomy project. The authors used the TAM to investigate the impact of personal characteristics on future intentions to integrate and use the interdisciplinary knowledge of economics and geography. Furthermore, our research results confirm the results of the original TAM when explaining acceptance of the use of interdisciplinary knowledge of economic and geography students at the beginning as well as at the end of the Spationomy project learning experiences. During the research, we mainly used the basic TAM proposed by Davis [15] and Davis et al. [16] and reshaped factors' items. In the case of the relationship between perceived usefulness (PU) and behavioral intention (BI) we followed recommendations of TAM 3 [45]. Nevertheless, there are some dissimilarities in the strength of the investigated connections among economic and geography students at different time aspects (at the beginning and the end of the project cycle).

By the research, we can also confirm that the Spationomy project has achieved its purpose, as both groups of students (economic and geography students) have acquired interdisciplinary knowledge and students intend to use it in the future. Research results of model testing reveal that both groups of students after the end of the Spationomy project have a very high future behavioral intention to use interdisciplinary knowledge of economics and geography (behavioral intention-BI-have very high beta values). For economic students' important relationships are those between perceived ease of use (PEOU) and perceived usefulness (PU) and between perceived usefulness (PU) and attitude toward use (AT) at the beginning, while after Spationomy project cycle also the relationship between attitude toward use (AT) and behavioral intention (BI) becomes statistically significant. This means that students intend to use the interdisciplinary knowledge of economics and geography in the future. For geography students at the beginning of the Spationomy project cycle (GeoBe) perceived ease of use (PEOU) does not affect perceived usefulness (PU) and attitude towards use (AT). These students are characterized by the fact that, at the beginning of the project cycle, perceived usefulness (PU) influences attitude towards use (AT) and behavioral intention (BI) but at the end of the project cycle (GeoAf), the connection between perceived ease of use (PEOU) and perceived usefulness (PU) becomes statistically significant, as well as the links between perceived usefulness (PU) and attitude toward use (AT) and perceived usefulness (PU) and behavioral intention (BI) are statistically stronger. This confirms 
that there are significant differences between the two groups of students (economic and geography students) and the differences are before they start to acquire interdisciplinary knowledge through the Spationomy project cycle and after the end of the project cycle (Hypothesis H1 is rejected).

Based on the presented results, we can reject the null hypothesis (H1), that there are no differences in the strength of the relationships in the conceptual model between two researched groups of students (economic students and geography students). The results of the research show that the interdisciplinary learning and teaching approach leads to positive attitudes of students towards interdisciplinary knowledge. Students of both studied disciplines (economic students and geography students) realized that achieving more holistic results requires the synergy of mutual, creative interdisciplinary cooperation between experts of different perspectives, that is, different fields of expertise. This emphasizes the requisite holism and interdependence as a very powerful tool, widely recognized as an important tool for fostering innovation and thus competitiveness $[6,7,12,17,20-23,28]$. Based on the presented research, its analysis and synthesis of findings, we can say that experts in the field of economics and geography should cooperate. It is becoming more than obvious that interdisciplinary knowledge and cooperation bring better results.

This spatial research of economic data showed results meaningfully. Gained strategic insight into a positive attitude of students towards interdisciplinary knowledge may provide useful information for both economic policymakers and practitioners (employees, business owners and/or managers) and especially for educational institutions of all levels of education. We recommend fostering the achievement of mutual creative interdisciplinary cooperation through the educational process by using modern teaching methods and contemporary IT/IS tools, and/or networking of subjects and different disciplines. This is a possible way to develop transversal competencies that are needed for different types of professions and different professions within them $[4,18,19]$. In this way, students-that is, future employees should be better prepared for the needs of the practice and should be able to perform the required tasks more easily and successfully. Additionally, employers should hire better-prepared employees, who are more and more capable of independent and interdependent work [17].

We, therefore, suggest that EU policymakers and the individual EU Member States promote interdisciplinary research and further integrate interdisciplinary approaches into their education systems. This research proves that an interdisciplinary approach promotes better results and is very well received among young people. The students involved in the project intend to use interdisciplinary knowledge in the future as well. Economists have perceived the practical value of the field of geography in their work and geographers have recognized the advantages of economics that they can efficiently implement in the field of their disciplines. The experience that the students gained by participating in the Spationomy project is unique for them and it also represents an important milestone in their thinking - to begin to think differently and more holistically. At the personal, organizational and social level, they will consider requisitely holism and interdependence as well as seek a synergistic upgrade of all aspects of their personal and professional life.

During the research of the topic, we did not find any comparable research that would investigate the impact of GIS or other IT/IS based tools on geographic students through the TAM. Also, this represents an important implication of this paper for the theory and practice of this research area.

Our research has some limitations, which might represent possibilities for further research, especially regarding the implications for educators. Namely, in modern conditions of achieving competitive advantages of organizations, employees must think out-of-the-box and look for better solutions for a better future, taking into account interdisciplinary interdependence. They need to develop transversal competencies and achieve synergies through mutually interdisciplinary cooperation. In order to achieve this, it is necessary to introduce changes in the education systems, as we mentioned earlier. The teaching/learning process should include tailor-made approaches to learning interdisciplinary areas. Statistically confirmed and proven, this applies to the field of economics and geography and we similarly suggest examining other fields of various disciplines. For teachers to be able to carry out interdisciplinary education, they must follow the findings of mutual interdisciplinary 
cooperation towards achieving synergies presented in this article, too. So, they also had to be requisitely holistic and oriented into the interdependence of different professional fields. We suggest that the willingness of teachers and their level of possession of interdisciplinary knowledge is further explored in the future.

This research was indeed conducted on a limited sample of only two disciplines (economy and geography), represented by students from selected EU Member States participating in the Spationomy project. However, the encouraging results, which are pioneering in this area, show that this area is more than worth exploring further.

Basic implications of this paper for the research area are derived from the recognition, that TAM is suitable for an explanation of acceptance of the use of interdisciplinary knowledge of economic and geography students in the learning process. Additionally, we would like to expose the fact that during the research of the topic, we did not find any other comparable research that would investigate the impact of GIS or other IT/IS tool based on geography students through the TAM. Therefore, also, this represents an important implication for the research area.

The key findings of our research:

- Interdisciplinary context of economics and business and geography synergy is growing rapidly (bibliometric analysis in Section 2.3).

- $\quad$ TAM can be used to explore the interdependence of business and geography knowledge in terms of IT tools.

- The acquisition of interdisciplinary knowledge within the Spationomy project influenced the behavioral intentions of both groups of students studied (economic students and geography students).

- There are differences in acceptance of interdisciplinary knowledge between two researched groups of students.

We can conclude with the thought that the results of our research confirm the importance of linking economic and spatial geographical knowledge. This paper uses the TAM framework for the research of economic and geography students' attitude towards interdisciplinary knowledge. Research results about students' future behavioral intention to use IK/IS tools showed that economic and geography students studied had acquired interdisciplinary knowledge and they intend to use it also in the future.

Author Contributions: All authors were involved in all parts of paper writing. All authors wrote, revised and approved the manuscript. Mostly they contributed to conceptualisation: Simona Sternad Zabukovšek, and Polona Tominc; literature review: Samo Bobek and Tjaša Štrukelj, bibliometric analysis: Polona Tominc; research model: Polona Tominc and Simona Sternad Zabukovšek; hypotheses: Samo Bobek and Polona Tominc; methodology, Simona Sternad Zabukovšek and Polona Tominc; research results and analysis: Simona Sternad Zabukovšek and Tjaša Štrukelj; discussion: Simona Sternad Zabukovšek, Samo Bobek, Polona Tominc, Tjaša Štrukelj; conclusions and further research recommendations: Polona Tominc, Samo Bobek and Tjaša Štrukelj; selected strategic viewpoints: Tjaša Štrukelj; formation: Simona Sternad Zabukovšek and Tjaša Štrukelj; overview: Polona Tominc, Samo Bobek and Tjaša Štrukelj. First author: Simona Sternad Zabukovšek Second author: Polona Tominc Third author: Samo Bobek Leading author: Tjaša Štrukelj. All authors have read and agreed to the published version of the manuscript.

Funding: This research was funded by the European Union, Erasmus+ programme, grant number 2019-1-CZ01-KA203-061374. The authors acknowledge the financial support from the Slovenian Research Agency (research core funding No. P5-0023).

Conflicts of Interest: The authors declare no conflict of interest.

\section{Abbreviations}

Economic students (Eco), geography students (Geo), before the beginning of the project cycle (Be), after the project cycle (Af), perceived ease of use (PEOU), perceived usefulness (PU), attitudes toward use (AT), behavioral intention (BI), Technology Acceptance Model (TAM), information technology/information system (IT/IS), interdisciplinary knowledge (IK). 


\section{References}

1. Benson, E.; Hansen, J.; Schwartz, A., Jr.; Smersh, G. Pricing residential amenities: The value of a view. J. Real Estate Financ. Econ. 1998, 16, 55-73. [CrossRef]

2. Robinson, P.; Genskow, K.; Shaw, B.; Shepard, R. Barriers and opportunities for integrating social science into natural resource management: Lessons from National Estuarine Research Reserves. Env. Manag. 2012, 50, 998-1011. [CrossRef] [PubMed]

3. Yue, S.; Wen, Y.; Chen, M.; Lu, G.; Hu, D.; Zhang, F. A data description model for reusing, sharing and integrating geo-analysis models. Env. Earth Sci 2015, 74, 7081-7099. [CrossRef]

4. Tominc, P.; Paszto, V.; Bobek, S.; Sternad Zabukovšek, S. Integration and use of the interdisciplinary knowledge in the field of spatial and economic/business sciences. Croat. J. Educ. 2019, 21, 861-892.

5. Shen, J.; Sung, S.; Zhang, D. Toward an analytic framework of Interdisciplinary Reasoning and Communication (IRC) processes in science. Int. J. Sci. Educ. 2015, 37, 2809-2835. [CrossRef]

6. Mulej, M.; Božičnik, S.; Čančer, V.; Hrast, A.; Jurše, K.; Kajzer, Š.; Knez-Riedl, J.; Jere Lazanski, T.; Mlakar, T.; Mulej, N.; et al. Dialectical Systems Thinking and the Law of Requisite Holism Concerning Innovation; Emergent Publications: Litchfield Park, Arizona, 2013.

7. ISO. ISO 26000, Social Responsibility: Discovering ISO 26000 (online); ISO-International Organization for Standardization: Switzerland, Geneva, 2010; Available online: http://www.iso.org/iso/discovering_iso_26000. pdf (accessed on 29 June 2011).

8. Agliari, A.; Commendatore, P.; Foroni, I.; Kubin, I. Expectations and industry location: A discrete time dynamical analysis. Decis. Econ Finan 2014, 37, 3-26. [CrossRef]

9. Rae, A.; Sener, R. How website users segment a city: The geography of housing search in London. Cites 2016, 52, 140-147. [CrossRef]

10. Hu, L.; He, S.; Luo, Y.; Su, S.; Xin, J.; Weng, M. A social-media-based approach to assessing the effectiveness of equitable housing policy in mitigating education accessibility induced social inequalities in Shanghai, China. Land Use Policy 2020, 94, 104513. [CrossRef]

11. Macků, K.; Caha, J.; Pászto, V.; Tuček, P. Subjective or Objective? How Objective Measures Relate to Subjective Life Satisfaction in Europe. Isprs Int. J. Geo-Inf 2020, 9, 320.

12. Dankova, P.; Valeva, M.; Štrukelj, T. A Comparative Analysis of International CSR Standards as Enterprise Policy/Governance Innovation Guidelines. Syst. Res. Behav. Sci. 2015, 32, 152-159. [CrossRef]

13. Jürgens, C.; Moos, N.; Redecker, A.P. Spationomy—Spatial exploration of economic data-An interdisciplinary geomatics project. Kn-J. Cartogr. Geogr. Inf. 2018, 2018, 66-71.

14. Pászto, V.; Jürgens, C.; Tominc, P.; Burian, J. (Eds.) Spationomy: Spatial Exploration of Economic Data and Methods of Interdisciplinary Analytics; Springer, Cop.: Cham, Switzerland, 2020; Available online: https://link.springer.com/book/10.1007/978-3-030-26626-4\#about (accessed on 20 March 2020). [CrossRef]

15. Davis, F.D. Perceived usefulness, perceived ease of use and user acceptance of information technology. Mis $Q$. 1989, 13, 319-340. [CrossRef]

16. Davis, F.D.; Bagozzi, R.P.; Warshaw, P.R. User acceptance of computer technology: A comparison of two theoretical models. Manag. Sci. 1989, 35, 982-1003. [CrossRef]

17. Duh, M.; Belak, J.; Štrukelj, T. Innovative approach in developing competences for business practice. In Handbook of Research on Enhancing Innovation in Higher Education Institutions; Babić, V., Nedelko, Z., Eds.; IGI Global: Hershey, PA, USA, 2020; pp. 428-463.

18. Sternad Zabukovšek, S.; Shah Bharadwaj, S.; Bobek, S.; Štrukelj, T. Technology acceptance model-based research on differences of enterprise resources planning systems use in India and the European Union. Inžinerinąe Ekon. 2019, 30, 326-338.

19. Štrukelj, T.; Zlatanović, D.; Nikolić, J.; Sternad Zabukovšek, S. A cyber-systemic learning action approach towards selected students' competencies development. Kybernetes 2019, 48, 1516-1533. [CrossRef]

20. Mulej, M. Dialektična teorija sistemov in ljudski reki. Naše Gospod. 1974, 21, 207-212.

21. Duh, M.; Štrukelj, T. Integration and requisite holism of the enterprises' governance and management as precondition for coping with global environmental changes. Acta Polytech. Hung. 2011, 8, 41-60.

22. Štrukelj, T.; Šuligoj, M. Holism and social responsibility for tourism enterprise governance. Kybernetes 2014, 43, 394-412. [CrossRef] 
23. Štrukelj, T.; Sternad Zabukovšek, S. Enterprise values and enterprise policy interdependence. Ekon. Istraživanja-Ecopnomics Res. 2019, 32, 2829-2849.

24. Štrukelj, T.; Nikolić, J.; Zlatanović, D.; Sternad Zabukovšek, S. A strategic model for sustainable business policy development. Sustainability 2020, 12, 526. [CrossRef]

25. Bertalanffy, L.V. An outline of general system theory. Br. J. Philos. Sci. 1950, 1, 134-165. [CrossRef]

26. Bertalanffy, L.V. General Systems Theory. Foundations, Development, Applications, 6th ed.; Braziller: New York, NY, USA, 1979.

27. Wiener, N. Cybernetics or Control and Communication in the Animal and the Machine; MIT Press: Cambridge, MA, USA, 1948.

28. Zlatanović, D.; Mulej, M. Soft-systems approaches to knowledge-cum-values management as innovation drivers. Balt. J. Manag. 2015, 10, 497-518. [CrossRef]

29. Brouder, P.; Eriksson, R.H. Staying power: What influences micro-firm survival in tourism? Tour. Geogr. 2013, 15, 125-164. [CrossRef]

30. Schulz, C.; Bailey, I. The green economy and post-growth regimes: Opportunities and challenges for economic geography. Geogr. Ann. Ser. B: Hum. Geogr. 2014, 96, 277-291. [CrossRef]

31. Terhorst, P.; Erkuş-Öztürk, H. Urban tourism and spatial segmentation in the field of restaurants: The case of Amsterdam. Int. J. Cult. Tour. Hosp. Res. 2015, 9, 85-102.

32. Burnač, D.; Erker, B.; Sternad Zabukovšek, S.; Bobek, S. Spatial informatics in water supply management: The case of Mariborski vodovod. In Spationomy: Spatial Exploration of Economic Data and Methods of Interdisciplinary Analytics; Pászto, V., Jürgens, C., Tominc, P., Burian, J., Eds.; Springer, Cop.: Cham, Switzerland, 2020; pp. 243-255.

33. Costa, C.; Ferreira, E.; Bento, F.; Aparicio, A. Enterprise resource planning adoption and satisfaction determinants. Comput. Hum. Behav. 2016, 63, 659-671. [CrossRef]

34. Fishbein, M.; Ajzen, I. Belief, Attitude, Intention and Behaviour: An Introduction to Theory and Research; Addison-Wesley: Reading, MA, USA, 1975.

35. Ajzen, I. The theory of planned behaviour. Organ. Behav. Hum. Decis. Process. 1991, 50, 179-211. [CrossRef]

36. Rogers, E. Diffusion of Innovations, 5th ed.; Free Press: New York, NY, USA, 2003.

37. Poon, S.; Swatman, P. An exploratory study of small business internet commerce issues. Inf. Manag. 1999, 35, 9-18. [CrossRef]

38. Tornatzky, L.; Fleisher, M. The process of Technology Innovation; Lexington Books: Lexington, MA, USA, 1990.

39. Calderia, M.; Ward, J. Using resource-based theory to interpret the successful adoption and use of information systems and technology in manufacturing small and medium-sized enterprises. Eur. J. Inf. Syst. 2003, 12, 127-141. [CrossRef]

40. Venkatesh, V.; Davis, F.D. A theoretical extension of the technology acceptance model: Four longitudinal field studies. Manag. Sci. 2000, 46, 186-205. [CrossRef]

41. Lu, J.; Chun-Sheng, Y.; Liu, C.; Yao, J.E. Technology acceptance model for wireless internet. Int. Res. Electron. Netw. Appl. Policy 2003, 13, 206-222. [CrossRef]

42. Liu, L.; Ma, Q. Perceived system performance: A test of an extended technology acceptance model. J. Organ. End User Comput. 2006, 18, 1-24. [CrossRef]

43. Amoako-Gyampah, K.; Salam, A.F. An extension of the technology acceptance model in an ERP implementation environment. Inf. Manag. 2004, 41, 731-745. [CrossRef]

44. Lee, D.H.; Lee, S.M.; Olson, D.L.; Chung, S.H. The effect of organisational support on ERP implementation. Ind. Manag. Data Syst. 2010, 110, 269-283. [CrossRef]

45. Venkatesh, V.; Bala, H. Technology acceptance model 3 and a research agenda on interventions. Decis. Sci. 2008, 39, 273-315. [CrossRef]

46. Shih, Y.Y.; Huang, S.S. The actual usage of ERP systems: An extended technology acceptance perspective. J. Res. Pract. Inf. Technol. 2009, 41, 263-276.

47. Sternad, S.; Bobek, S. TAM-based external factors related to ERP solutions acceptance in organisations. Int. J. Inf. Syst. Proj. Manag. 2013, 1, 25-38.

48. Sternad, S.; Bobek, S. Comparative analysis of acceptance factors for SAP and Microsoft Dynamics NAV ERP solutions in their maturity use phase: Enterprise 2.0 issues. In Handbook of Research on Enterprise 2.0: Technological Social and Organisational Dimensions; Business Science Reference; Cruz-Cunha, M.M., Moreira, F., Varajao, J., Eds.; IGI Global: New York, NY, USA, 2014; pp. 389-415. 
49. Calisir, F.; Gumussoy, C.A.; Bayram, A. Predicting the behavioural intention to use enterprise resource planning systems-An exploratory extension of the technology acceptance model. Manag. Res. News 2009, 32, 597-613. [CrossRef]

50. Mayeh, M.; Ramayah, T.; Mishra, A. The role of absorptive capacity, communication and trust in ERP adoption. J. Syst. Softw. 2016, 119, 58-69. [CrossRef]

51. Sternad, S.; Gradišar, M.; Bobek, S. The influence of external factors on routine ERP usage. Ind. Manag. + Data Syst. 2011, 111, 1511-1530. [CrossRef]

52. Sun, Y.; Bhattacherjee, A.; Ma, Q. Extending technology usage to work settings: The role of perceived work compatibility in ERP implementation. Inf. Manag. 2009, 46, 351-356. [CrossRef]

53. Sternad Zabukovšek, S.; Kalinić, Z.; Bobek, S.; Tominc, P. SEM-ANN based research of factors' impact on extended use of ERP systems. Cent. Eur. J. Oper. Res. 2019, 27, 703-735. [CrossRef]

54. Youngberg, E.; Olsen, D.; Hauser, K. Determinants of professionally autonomous end user acceptance in an enterprise resource planning system environment. Int. J. Inf. Manag. 2009, 29, 138-144. [CrossRef]

55. Shivers-Blackwell, S.L.; Charles, A.C. Ready, set, go: Examining student readiness to use ERP technology. J. Manag. Dev. 2006, 25, 795-805. [CrossRef]

56. Bradley, J.; Lee, C.C. ERP training and user satisfaction: A case study. Int. J. Enterp. Inf. Syst. 2007, 3, 33-50. [CrossRef]

57. Scott, J.E.; Walczak, S. Cognitive engagement with a multimedia ERP training tool: Assessing computer self-efficacy and technology acceptance. Inf. Manag. 2009, 46, 221-232. [CrossRef]

58. Sternad Zabukovšek, S.; Picek, R.; Bobek, S.; Šišovska, I.; Tominc, P. Technology acceptance model based study of students' attitudes toward use of enterprise resource planning solutions. J. Inf. Organ. Sci. 2019, 43, 49-71. [CrossRef]

59. Alzighaibi, A.; Mohammadian, M.; Talukder, M. Factors affecting the adoption of GIS systems in the public sector in saudi arabia and their impact on organizational performance. J. Geogr. Inf. Syst. 2016, 8, 396-411. [CrossRef]

60. Lay, J.-G.; Chi, Y.-L.; Hsieh, Y.-S.; Chen, Y.-W. What influences geography teachers' usage of geographic information systems? A structural equation analysis. Comput. Educ. 2013, 62, 191-195. [CrossRef]

61. Çakar, B. Factors Affecting Police Officers' Acceptance of GIS Technologies: A study of the Turkish National Police. Ph.D. Thesis, University of Denton, Denton, TX, USA, 2011.

62. Chang, G.; Caneday, L. Web-based GIS in tourism information search: Perceptions, tasks and trip attributes. Tour. Manag. 2011, 32, 1435-1437. [CrossRef]

63. Loukis, E.; Xenakis, A.; Peters, R.; Charalabidis, Y. Using Gis Tools to Support E_Participation-A systematic evaluation. In Electronic Participation: ePart 2010-Lecture Notes in Computer Science; Tambouris, E., Macintosh, A., Glassey, O., Eds.; Springer: Berlin/Heidelberg, Germany, 2010.

64. Mirda, J.; Baharudin, A.S.; Karkonasasi, K. Technology acceptance factors affecting intention to adopt Geographical Information System (GIS) among the Local Governments in West Aceh, Sumatera, Indonesia. Int. J. Appl. Eng. Res. 2016, 11, 2711-2716.

65. Adu Gyamfi, S. Informal tools in formal context: Adoption of web 2.0 technologies among geography student teachers in Ghana. Int. J. Educ. Dev. Using Ict 2017, 13, 24-40.

66. Tan, K.L. Acceptance of Personal Digital assistants for Geography Fieldwork. Ph.D. Thesis, Nanyang Technological University, Singapore, 2006.

67. Gundolf, K.; Filser, M. Management research and religion: A citation analysis. J. Bus. Ethics 2013, 112, 177-185. [CrossRef]

68. Van Eck, N.J. Methodological Advances in Bibliometric Mapping of Science. 2011. Available online: http: //repub.eur.nl/pub/26509/EPS2011247LIS9789058922915.pdf (accessed on 20 August 2019).

69. van Eck, N.J.; Waltman, L. VOSviewer Manual; Univeristeit Leiden: Leiden, The Netherlands, 2013.

70. Letchumanan, M.; Muniandy, B. Migrating to e-book: A study on perceived usefulness and ease of use. Libr. Hi Tech New Inc. Online Cd Notes 2013, 30, 319-340. [CrossRef]

71. Park, S.Y. An analysis of the technology acceptance model in understanding university students' behavioral intention to use e-learning. Educ. Technol. Soc. 2009, 12, 150-162.

72. Šebjan, U.; Tominc, P. Impact of support of teacher and compatibility with needs of study on usefulness of SPSS by students. Comput. Hum. Behav. 2015, 53, 354-365. [CrossRef]

73. Chin, W.W. Issues and opinion on structural equation modeling. Mis Q. 1998, 22, vii-xvi. 
74. Ringle, C.M.; Wende, S.; Becker, J.-M. SmartPLS 3. SmartPLS GmbH: Boenningstedt. 2015. Available online: http://www.smartpls.com (accessed on 12 May 2018).

75. Henseler, J.; Ringle, C.M.; Sinkovics, R.R. The Use of Partial Least Squares Path Modeling in International Marketing. New Chall. Int. Mark. (Adv. Int. Mark.) 2009, 20, 277-319.

76. Henseler, J.; Ringle, C.M.; Sarstedt, M. A new criterion for assessing discriminant validity in variance-based structural equation modelling. J. Acad. Mark. Sci. 2015, 43, 115-135. [CrossRef]

77. Garson, G.D. Partial Least Squares: Regression \& Structural Equation Models; Garson and Statistical Associates Publishing: Asheboro, NC, USA, 2016.

78. Fornell, C.; Larcker, D.F. Evaluating structural equation models with unobservable variables and measurements errors. J. Mark. Res. 1981, 18, 39-50. [CrossRef]

79. Henseler, J.; Hubona, G.; Ray, P.A. Using PLS path modelling in new technology research: Updated guidelines. Ind. Manag. Data Syst. 2016, 116, 2-20. [CrossRef]

80. Kline, R.B. Principles and Practice of Structural Equation Modelling; Guilford Press: New York, NY, USA, 2011.

81. Hu, L.T.; Bantler, P.M. Fit indices in covariance structure modelling: Sensitivity to underparameterized model misspecification. Psychol. Methods 1998, 3, 233-249. [CrossRef]

82. Sternad Zabukovšek, S.; Štrukelj, T.; Tominc, P.; Bobek, S. Factors influencing attitudes of students toward ERP systems as computer-aided learning environments. In Handbook of Research on Enhancing Innovation in Higher Education Institutions; Nedelko, Z., Babić, V., Eds.; IGI Global: New York, NY, USA, 2020; pp. 485-522.

(C) 2020 by the authors. Licensee MDPI, Basel, Switzerland. This article is an open access article distributed under the terms and conditions of the Creative Commons Attribution (CC BY) license (http://creativecommons.org/licenses/by/4.0/). 